NBER WORKING PAPERS SERIES

OBSTACLES TO TRANSFORMING CENTRALLY-PLANNED ECONOMIES: THE ROLE OF CAPITAL MARKETS

\author{
Guillermo A. Calvo \\ Jacob A. Frenkel
}

Working Paper No. 3776
NATIONAL BUREAU OF ECONOMIC RESEARCH
1050 Massachusetts Avenue
Cambridge, MA 02138
July 1991

This paper is part of NBER's research program in International Studies. Any opinions expressed are those of the authors and not those of the National Bureau of Economic Research. 
NBER Working Paper \#3776 July 1991

\title{
OBSTACLES TO TRANSFORMING CENTRALLY-PLANNED ECONOMIES: THE ROLE OF CAPITAL MARKETS
}

\begin{abstract}
This paper identifies obstacles hindering the transformation of centrally-planned economies (CPEs) into well-functioning market economies. The analysis is motivated by the recent experience with economic transformation and restructuring in Eastern Europe and the U.S.S.R. The economic system in CPEs is highly distorted. Prices do not represent real social costs, incentives systems are absent, losses of unprofitable state-owned enterprises are automatically financed, legislations vital for the functioning of markets are not in place, private ownership and property rights are underdeveloped, bankruptcy laws are absent, markets are missing, shortages prevail and, occasionally, inflation is high.

The obstacles identified relate to (i) anticipatory dynamics, (ii) monetary overhang and the budget, and (iii) underdeveloped credit markets. It is demonstrated that these obstacles inhibit the effectiveness of price reform, monetary and credit policies, and trade liberalization. The analysis focuses on various ways to remove the obstacles. In this regard, a special examination is made of the implications of "cleaning" the balance sheets of enterprises and banks from nonperforming loans, as well as ways to enhance credibility. In the absence of such measures, privatization will be difficult since the necessary information about creditworthiness of firms is lacking. The paper concludes with a brief discussion of sequencing, "safety nets," and their associated obstacles.
\end{abstract}

Guillermo A. Calvo International Monetary Fund 700 19th Street, NW Washington, DC 20431
Jacob A. Frenkel

International Monetary Fund 700 19th Street, NW Washington, DC 20431 and NBER 
Th1s paper 1dentifies obstacles hindering the transformation of centrally-planned economies (CPEs) into well-functloning market economles. The analysis is motivated by the recent experience with economic transformation and restructuring in Eastern Europe and the U.S.S.R. The economic system in CPEs is highly distorted. Prices do not represent real social costs, incentives systems are absent, losses of unproficable stateowned enterprises are automatically financed, legislations vital for the functioning of markets are not in place, private ownership and property rights are underdeveloped, bankruptcy laws are absent, markets are missing, shortages prevall and, occasionally, inflation is high.

During the transition period the old central-planning system is dismantled (or 1s collapsing) while the new market system (and its associated 1nstitutions and policles) is still not in place. During this transition, the economy is not any more a CPE but has not yet become a fully-functioning market economy--1t is referred to as being a "previously centrally-planned economy" (PCPE).

The obstacles 1dentified in subsequent sections relate to (1) antic1patory dynamics, (11) monetary overhang and the budget, and (111) underdeveloped credit markets. We demonstrate how these obstacles inhibit the effectiveness of price reform, monetary and credit policles, and trade liberallzation. We explore various ways to remove the obstacles. In this regard, we examine the 1mplications of "cleaning" the balance sheets of enterprises and banks from nonperforming loans, as well as ways to enhance credibility. The paper concludes with a brief discussion of sequencing, "safety nets," and the1r associated obstacles. 


\section{Anticipatory dynamics}

The process of economic transformation and restructuring is long and complex. The pre-reform period typically starts with a lengthy delay between the tine of the political decision to launch a transformation program, and the time of its actual implementation. During this pre-reform period, economic policies are negotiated and designed, political consensus is cemented, and key features of the institutional infrastructure are developed. In the pre-reform period actual policy reform measures are not yet implemented, and many of the basic features of the economic system are still of the CPE variety. However, the private sector, being clearly aware that fundamental changes are planned, modifies the patterns of its consumption and assets holdings. As illustrated by the recent experience in Bulgaria, Czechoslovakia, Romania and the U.S.S.R., the private sector's behavior during the pre-reform period is governed by the expectations of the reform rather than by the policy measures themselves. Such anticipatory actions reflect themselves in prices, exchange rates, rates of interest, foreign exchange reserves and other important economic variables.

Such anticipatory changes are not without cost. Since many of them occur prior to the removal of administered prices, they may aggravate the welfare cost of existing distortions. In addition, since the private sector and policymakers are not fully famillar with the workings of market forces, they may get confused observing that key economic variables exhibit sharp changes, while economic fundamentals (policy measures and institutions) have not yet changed. Faced with these realities, policymakers, whose mentality and attitude may still reflect the legacy of central planners, may be 
tempted to offset the undesirable consequences of anticipatory dynamics. However, in order to succeed in offsetting such disruptions, policymakers would need to adopt an extremely complex fine-tuning strategy requiring a detalled and precise knowledge of the economic system. Since such knowledge cannot be assumed, the fine-tuning strategy is likely to add to the "noise" In the economic system, amplify the confusion, and erode credibility (Calvo and FrenkeI (1991a)).

These considerations suggest that the transitional pre-reform period characterizing the early stages of transformation should be as short as possible. The most effective way to remove the obstacle of anticipatory dynamics is through quick articulation and implementation of the program-thereby reducing the likelihood that anticipatory dynamics aggravates the distortions--and through the adoption of clear policy rules--thereby enhance credibility and reduce the likelihood of noisy fine-tuning.

\section{Monetary overhang and the budget}

One of the features of PCPEs, especially during the early stages of transformation, is the presence of a "monetary overhang." This overhang has accumulated over the years. Governments in the CPEs have financed their budget deficits through money creation, and enterprises have enjoyed "soft" budget constraints as losses were automatically financed through credit creation. At the same time, the shortages of goods were not allowed to result in an open inflation, which was suppressed by the governments' administered-pricing strategy. 
Saddled with the monetary overhang, transactions in the economy became inefficient, as individuals have spent excessive time and resources in "chasing" goods and standing in queues, rather than engaging themselves in socially-productive activities. This has disrupted the production process as workers and managers have had to divide their attention between their jobs and "shopping" activities. Furthermore, the shortages reduced the ability to exchange money for goods, eroded the liquidity and "moneyness" of money, and encouraged costly barter transactions. Thus, the overhang distorts the allocation of resources. In addition, it is an obstacle to the adoption of other desirable measures like price liberalization and currency convertibility.

There are essentially three mechanisms to reduce the liquidity overhang. First, by increasing the attractiveness of domestic liquid assets through a rise in the rate of interest paid on domestic-currency deposits; second, through a rise in prices associated with the price liberalization; and, third, through a reduction in liquidity. The first mechanism raises the demand for real liquid assets, while the latter two lower their real supply. These mechanisms have been emphasized in the recent debate on the means to reduce the monetary overhang in the U.S.S.R., and, to some extent, in Bulgaria and Romania. In what follows, we argue that a successful implementation of each of the above-mentioned mechanisms must overcome some of the obstacles related to tax incidence.

Regarding the first mechanism, we note that a rise in the deposit rate (especially in PCPEs) has adverse implications for the government budget. In such economles the banking system is "owned" to a large extent by the 
government. Therefore, a rise in the rate of interest paid by banks is a drain on the budget. In fact, in many respects bank deposits may be regarded as public debt, and interest on deposits may be viewed as publicdebt service. From this perspective, credit and budget policies are linked to each other, as the rise in the deposit rate needs to be financed through new taxes. The budgetary drain is higher, the lower is the interest elasticity of the demand for real liquid assets. The effectiveness of this mechanism in alleviating the overhang depends on the capacity of the tax system to generate the necessary tax revenue, and on the distributive and efficiency implications of the associated incidence of the tax.

The second mechanism for eliminating the monetary overhang--a rise in the price level--carries with it the danger of igniting inflation. Therefore, the effectiveness of this mechanism depends on the capacity of the government to prevent the slippage of what should be a once-and-for-all price rise into an inflation spiral. Furthermore, since the rise in the price level represents a tax on the real value of domestic liquid asset, its desirability also depends upon the specific incidence of the tax, and on 1 ts effects on the efficlency of resource allocation, and on the capacity of the government to secure its political support.

The third mechanism for eliminating the monetary overhang is a reduction in the nominal stock of money. This reduction can be effected through either a direct confiscation of money (e.g., a monetary reform), or an absorption of money by open market sales. Each of these two methods confronts important obstacles. 
Monetary reform may be highly effective in bringing about a rapid elfmination of the overhang. Indeed, there have been several historfcal episodes in which such reforms were implemented successfully, especially in the context of a comprehensive program dealing with hyperinflation. However, since the incidence of the tax assoclated with a monetary reform is not distributed evenly across the population, it may erode the political support necessary for 1 ts successful implementation. Safety nets in the form of approprlate fncome policies may need to be designed to secure the political support. Furthermore, the direction of the effects of this confiscatory policy (along with the accompanying income policies) on economic efficiency and on credibility is not unambiguous.

The reduction of liquidity through open market sales also confronts obstacles. In PCPEs the possibilfty of conducting open market sales are Ifmited by the absence of conventional financial instruments and by underdeveloped capital markets. However, since the government owns a large portion of the economy's assets and, In many cases, wishes to undertake a privatization program, it can absorb the excess liquidity through sales of houses and state enterprises. In addition, the increased size of the market economy resulting from such privatization may raise the demand for liquidity and reduce the size of the overhang as transactions shift from the barter to the monetized sector.

The obstacles to privatization are well known (see, for example, Borensztein and Kumar (1991), Frydman and Rapaczynsk1 (1990) and Lfpton and Sachs (1990)). They include the problems of establishing a "falr" market price for an enterprise without the help of a well-functioning market place, 
developing the legal infrastructure necessary for the effective use of entrepreneurial drive, adopting bankruptcy laws, developing domestic credit and financial markets necessary for intermediation, the redistribution of rents, the potential for corruption, etc.

In addition, privatization has profound implications on the budget, and its effectiveness also depends on the incidence of the tax. On the one hand, sales of state enterprises generate (nonrecurring) revenue (which cannot be spent for, otherwise, a new monetary overhang would be generated); on the other, the transfer of income-producing assets to the private sector results in a (recurring) loss of future revenue. To make up for this loss of revenue the government must find new sources of recurring income.

In searching for such new sources, the obstacle of "time inconsistency" needs to be overcome. The government will be tempted to levy new (previously unannounced) taxes on the enterprises that were fust sold to the private sector. The strategy of levying such surprise taxes, however, may prove to be counterproductive. For, potential buyers, in setting their bids for state enterprises, will take into account the possibility that the government will be tempted to raise taxes. Such anticipations tend, therefore, to lower the market price of state enterprises, reduce the proceeds from privatization, and leave the monetary-overhang problem unsolved. To prevent the erosion of privatization proceeds, the government must provide reliable and bellevable signals that such surprise taxes will not be levied. To produce such credible signals, the government must demonstrate 1ts capacity and unequivocal commltment to tap new sources of tax revenue. These new sources of tax revenue must cover the entire loss of 
recurrent revenue induced by the privatization program, thereby reducing the likelihood that, after the event, the government would levy new taxes. To reduce uncertainty such sources of revenue should be secured prior to privatization. The privatization program will succeed in eliminating the monetary overhang if the government replaces the lost revenue by levying new taxes on entities other than the newly-privatized enterprises.

Similar considerations apply to proposals of absorbing the monetary overhang by sales of housing. Unless the government reduces significantly the rent-control provisions, there will not be great incentives for tenants, who pay ridiculously low rents, to offer high price for housing. Thus, the reduction in the rent-control provisions represent a specific incidence of the tax (falling entirely on the tenants). The adoption of such a tax, however, signifies a major political obstacle.

The foregoing analysis of the various means to eliminate monetary overhang reveals that in all cases the private sector ends up being taxed by the full amount of the overhang. The choice among the alternative means would reflect the relative desirability of the different incidence of the tax.

\section{Credit markets and economic transformation}

The difficulties associated with the early phases of transformation reflect the unprecedented changes in the policy environment superinposed on the collapsing central-planning system. The fundamental transformation induces large-scale dislocations as inefficient sectors are expected to get out of business, while other sectors are expected to expand in response to market incentives. In addition, faced by market prices and positive real 
interest rates, enterprises that accumulated large inventories under the administered-price/low-1nterest-rate regime are likely to find their inventories stock to be excessive. While running down inventories, production declines (as firms sell from inventories rather than from new production) and the demand facing inventory-producing firms falls.

In this section we focus on the special role played by credit and financlal markets, and argue that the 1mperfections prevailing in PCPEs are major obstacles to an effective transformation. They can give rise to a "bad" equilibrium in which growth is low and the incentives to undertake efficient investments are stifled. We also argue that the removal of these obstacles yields a distinctly superior "good" equilibrium.

To motivate the analysis, it is worth recalling the main features of credit and financial markets in PCPEs. These markets lack depth and breadth. The complex information system necessary to assess risk and creditworthiness is underdeveloped. For, in the past, while being a CPE there were no incentives to accumulate such information. In the CPE losses of enterprises were automatically financed and the government, being a "lender of last resort," provided comprehensive insurance without charging the appropriate premium. In many cases this implicit insurance also encouraged overextension of interenterprise credit.

The interdependence among the balance sheets of enterprises is one of the key obstacles impeding the operation of the market system. It makes it very difficult to distinguish between enterprises that are efficient and viable and those that are inefficlent and nonviable, thereby adding to the complexity of assessing creditworthiness of individual firms. The lack of 
information is especially pronounced, since the dramatic structural changes associated with the transformation process in PCPEs render the limited available information largely obsolete. Furthermore, in PCPEs policymakers are typically untested, the structure of property rights is not fully defined, and the private sector is unaccustomed to "market rules." These factors contribute to the uncertainty about policy response, and about the behavior of economic agents. The overall uncertainty is likely to affect adversely the profitability of enterprises, to reduce the market value of installed capital and, thus, to limit the capacity of enterprises to borrow against collateralized capital.

The imperfect information structure which makes it difficult to assess the creditworthiness of enterprises, superimposed on the complex web of interfirm credit which links the fortunes of efficient and inefficient enterprises, are major obstacles to a successful transformation. They may result in a "bad" equilibrium in which socially profitable long-term investments are crowded out by less profitable short-term investments. Such a "bad" equilibrium could arise if potential lenders lack the confidence that other lenders will stand ready to extend credit to cover enterprises' liquidity needs. This lack of confidence may especially prevail in PCPEs since there the information concerning the risk characteristics of specific enterprises is missing or is not widely available to potential lenders.

In addition to the lack of information about specific firms, the PCPEs exhibit a relatively high degree of economy-wide (systemic) risk due to the large structural changes and the unpredictability of the policy response. The likelihood of systemic risk is enhanced in PCPEs since their capital 
markets are underdeveloped: risk which could be diversifled in fullydeveloped capital markets may remain undiversified. Furthermore, the network of interfirm credit increases the risk that firm-specific shocks are spread across enterprises and, thereby, are transformed into economy-wide shocks. All of these factors taken together contribute to shortening the planning horizon of lenders and borrowers, and account for the tendency to undertake short-term rather than long-term investment projects (like Infrastructure investment)--even though the latter might be more desirable from the social point of view. Thus, a "bad" equilibrium ensues.

\section{Removing the obstacles}

The preceding discussion indicates that a major obstacle hindering transformation and ylelding a "bad" equilibrium is the underdevelopment of capital markets. Policies almed at reducing the likelihood of a "bad" equilibrium include measures that (1) improve the information system and the legal instruments avallable to lenders and Investors, and "clean" the balance sheets of enterprises and banks from "bad" debts, and (ii) enhance credibility. In what follows, we address these 1ssues.

\section{a. "Cleaning" the balance sheets}

An Improved Information system provides a better assessment of creditworthiness of individual firms and thereby removes an fmportant obstacle to lending. The development of a legal framework provides the instruments for the enforcement of contracts and the protection of property rights, thus removing another 1mportant obstacle to lending. Furthermore, the protection provided by the legal system encourages prospective lenders to engage in ventures that are socially desirable but that are deemed to be 
too risky in the absence of the legal safety net. Put differently, the legal protection reduces the need of prospective lenders to engage in selfinsurance by the accumulation of "excessive" (and socially-costly) information.

Finding appropriate ways to "clean" the balance sheets of enterprises and banks from "bad" debts would delink the fortunes of enterprises that ought to go out of business from those that should continue operations (see Brainard (1991)). A major challenge is to achieve this objective without imposing excessive costs to the budget and without hampering the incentive structure. The "cleaning" of books can be effected through either a cancellation or a socialization of debts. In doing so care should be taken to avoid the "moral hazard" that "cleaning" operations may introduce into the capital market.

Debt cancellation reduces the availability of working capital to creditor firms, and carries with it the danger of choking "good" enterprises whose cash-flow requirements depend critically on debt-service receipts. The government should consider, therefore, extending credits to such "good" firms. The identification of creditworthy economically-viable enterprises should be made simpler once the balance sheets have been "cleaned."

An additional difficulty with debt cancellation is that it may give rise to moral hazard problems. To avoid setting the precedent that interenterprise debts are not honored and are cancelable in what may seem to be an arbitrary manner, it is critical that this operation be viewed as a pure book-keeping device. In fact, since in many cases (prior to privatization) the debtor and creditor enterprises are not privately owned, 
the cancellation of interenterprise debts need not alter the distribution of income and wealth within the private sector. It could be argued, therefore, that such a cleaning operation helps to reduce the "moral hazard" that might be present once the enterprises, whose balance sheets are heavily loaded with such debts, are privately owned.

Delinking the fortunes of debtor and creditor enterprises through debt socialization, transforms the nature of debt and alters its risk characteristics without changing fts magnitude. In socializing the debt, the government engages in debt-for-debt swaps in which government obligations (e.g., treasury bills) are swapped for the claims that creditor firms and banks hold against other enterprises. In a sense, this operation serves to recapitalize creditor firms and banks by issuing government obligations in place of the non-performing assets. At the same time, the llabilities of debtor firms to other enterprises and banks are transformed into lfabilities to the government. By assuming the role of a financial Intermediary, the government (dfrectly, or indirectly through a bank acting on its behalf) helps to delink the fortunes of different enterprises. By servicing its own debt, the government ensures that the avallability of working capital for the creditor enterprise does not depend upon the debtor enterprise's capacity to pay. However, to secure its own capacity to pay when debtor enterprises get into debt-service difficulties, the government must have overcome an fmportant obstacle: It must have at its disposal a functional tax system capable of financing the debt-service obligations without resorting to inflationary finance. This underscores the urgency of an early development of an efficient tax system. 
In analogy with the earlier discussion of debt cancellations, it could be argued that the socialization of debt may also introduce "moral hazard" problems. For, a precedent may be set that the government steps in to bail out firms in financial difficulties, thereby reducing the incentives for firms to run their affairs prudently. However, as indicated earlier, prior to privatization the various enterprises are, in fact, owned by the government; therefore, the socialization of debt amounts to making explicit what is already implicit. Indeed, one of the benefits of undertaking debt socialization prior to privatization is that it reduces the risk that moralhazard problems would arise in the post-privatization stage.

A successful program of "cleaning" the balance sheets reduces the difficulties in pricing enterprises. This removes an important obstacle to an effective privatization program and enables the PCPE to reap the benefits from privatization. The beneficlal effects of privatization on the efficiency of resource allocation may be signiflcant if the privatization of state enterprises and the housing sector provides incentives for higher productivity and better maintenance of the capital stock. Such benefits are especially pronounced in PCPEs where, as argued above, domestic credit markets are in their infancy. In this regard, the opening of the economy to foreign investment can be highly beneficial. In addition to providing financial and managerial capital, privatization programs that encourage direct foreign participation can be useful in providing access to International capital markets. Foreign investors bring with them know-how, contacts, and information. Their presence and active participation yield the added benefit of improving the functioning of domestic capital markets. 


\section{b. Enhancing credibility}

A major obstacle to a successful transformation is the lack of credib1lity. To acquire credibility, pol1cymakers must demonstrate that they are willing to introduce a fundamental change in the manner by which policy is conducted. The adoption of a rule-based policy framework, rather than discretion, might reduce the perception of arbitrariness and, thereby, strengthen confidence in the policy-making process.

The advantages of rules (especially those that are simple and not excessively state-contingent) over discretion are particularly pronounced in PCPEs in which policymakers start giving a greater role to market signals. In this environment, discretionary actions may be counterproductive, since the structure of prices and other market signals reflect the prevailing distortions. Therefore, there is the danger that the discretionary actions are guided by the wrong signals. Policy rules that are simple are especially desirable where policymakers are untested. Furthermore, since in the CPEs discretion was the rule, a clear statement favoring rules over discretion could go a long way in signalling a basic change in the policy regime. The key challenge, however, is how to make such a statement credible.

Two elements of credibility are needed. First, the economic program must be credible. The program should be feasible, stand the test of professional scrutiny, and reflect the experience of and lessons from other episodes. Second, polfcy commitments must be credible. These commitments should not be susceptible to the "time inconsistency" problem, providing incentives to change policy direction in mid-course. Economic authorities 
make explicit or implicit pronouncements that influence the response of the private sector. In this sense, policymakers are the "dominant player" in the economic arena. The private sector shapes its economic behavior on the basis of expectations concerning the likely course of current and future policies. With the passage of time, the government, observing the behavior of the private sector, may be tempted to depart from the previouslyannounced policy intentions which, in turn, have governed the private sector's actions. This is the well-known "time inconsistency" problem which may hamper the credibility of policy commitments.

The two elements of credibility--of the economic program and of the policy commitments--are interdependent. For example, the likelihood that policy commitments may face "time inconsistency" problems increases, the higher is the credibility of the economic transformation program. For, a credible transformation program is likely to result in short-term hardships. It is liable, therefore, to generate political pressures and interest groups lobbying for mid-course changes, which may give rise to "time inconsistency." This possibility, in turn, may be anticipated by the private sector already in the earlier stages of the economic transformation process, and incorporated into its behavior. If this occurs, then market participants may end up giving excessive attention to the near term while discounting heavily longer-term prospects--thus generating a "bad" equilibrium. To avoid such difficulties and enhance the likelihood that a "good" equilibrium ensues, policymakers may find it useful to "tie" their own hands and thereby send a strong signal that the advantages of being the "dominant player" will not be used. 
It is useful to classify the methods by which the authorities can "tien thelr own hands into four categorles. First, the early steps of the new polfcy regime must entall actions that are sufficlently significant to provide a clear signal that a change in regime has occurred. Policy pronouncements accompanied by actions indicating that the commitment of the government to the transformation is "absolute" make policy reversals politically costly. The higher the political costs of policy reversals, the higher the credibility of policy pronouncements. Once a credible signal is provided, it would influence the expectations of the private sector about the future course of the new policy reglme and, in forming such expectations the private sector is 11 kely to lower the welght given to past policy fallures. Thus, the quick bullding of a track record imposes internal polftical constraints on the ab1lity of the government to reverse course. Second, the various branches of the pollcy-making apparatus can be designed so as to provide effective checks and balances protecting from "time inconsistency" problems. Examples are the establishment of a legally 1ndependent Central Bank, or a legal prohibition on Central Bank financing of government budget deficits, or a Constitutional amendment legislating balanced budgets. Such mechanisms contribute to the credibility of policy commitments by Imposing internal legal constraints on the ability of governments to abuse their "dominant player" role.

Third, the credibility of polfcy commitments can also be enhanced if the government "ties" 1 ts hands by entering into international agreements of varlous sorts. Examples are exchange-rate commitments, 11ke those undertaken by countrles joining the Exchange Rate Mechanism (ERM) of the 
European Monetary System, or like those undertaken by countries joining the General Agreement on Tariffs and Trade (GATT). These comitments impose external legal constraints on the use of specific policy instruments: the exchange rate in the case of the ERM, and tariffs or quotas in the case of the GATT.

Fourth, credibility can be further enhanced if the government chooses to "tie" its hands by adopting an economic program supported by an international financial institution, like the International Monetary Fund or the World Bank. The endorsement of experts representing the international financial commity enhances the credibility of the economic program. Furthermore, by making the financial support to the program conditional on the implementation of the prespecified policy measures, this form of "tieing" the hands imposes external economic and legal constraints, and contributes to the credibility of policy commitments.

The foregoing four methods by which the government can "tie" its hands are not mutually exclusive. In many cases governments may find it useful to employ some or all of these methods simultaneously so as to reinforce each other and enhance credibility. In this regard, however, the capacity of PCPEs to employ the internal (political and legal) constralnts is somewhat limited. In these cases, therefore, the external constraints should play a more prominent role in "tieing" governments' hands.

5. Capital markets, price reform, monetary policy and trade liberalization

In previous sections we have claimed that the underdevelopment of capital markets in PCPEs is an obstacle hampering the success of the 
transformation program. We have also identifled measures that would enhance the development of such markets. In this section, we argue that improving the functioning of capital markets also enhance the benefits from other key elements of the transformation program. This point is illustrated by reference to price reform, monetary policy and trade liberalization.

The removal of subsidies, the freeing-up of prices and the dismantilng of administered-pricing machinery is likely to result in a higher price level. Coupled with the tightened credit control and the segmentation of the underdeveloped domestic credit markets, such price rise may have profound negative supply-side effects. For, as noted earlier, in PCPEs the ability of enterprises to offset the rise in input prices, and the consequent fall in working capital by employing alternative sources of finance, is limited. Therefore, great care should be taken to ensure that "good" enterprises can replenish their eroded working capital so as to maintain their productive activities during the price-reform period. Thus, wel1-functioning capital markets enhance the benefits from price liberalization.

An early development of domestic capital markets also enhances the effectiveness of monetary policy. By its nature, monetary policy has aggregate effects on the economy. These effects impact on "good" and "bad" firms alike. Well-functioning credit markets, however, facilitates a separation between "good" and "bad" firms. While "good" firms can mitigate the contractionary effects of monetary policy by relying on other sources of finance, "bad" firms cannot. The latter do not have access to capital markets and, therefore, they must elther cease operations or restructure. 
Accordingly, the capacity of monetary policy (which is inherently unrefined) to yield socially desirable outcomes is enhanced if it operates in an environment of well-functioning capital markets. In addition, the restructuring of capital markets should enhance the incentive effects of monetary and credit policies. Once enterprises are aware that access to credit markets is limited and that credits can only be obtained by "good" firms, it is likely that they will respond more promptly and effectively to signals conveyed by monetary and credit policies.

The benefits from trade liberalization also depend on the quality of capital markets. Trade liberalization provides the economy with the "right" price signals. Exposure to world prices helps to demonopolize the economy, enhance competition, and improve the allocation of resources. However, in adjusting to the removal of protection, even "good" and economically viable firms may require credit. The adoption of "hard" budget constraints eliminates the automatic financing of enterprises' deficits by the government. Without sufficient access to capital markets such "good" firms may be forced out of business, thereby reducing the benefits from trade liberalization. Moreover, in attempting to protect themselves, the "good" but endangered enterprises may be tempted to join the "bad" and economically non-viable enterprises in lobbying against trade liberalization, thereby reducing the likelihood that liberalization will be adopted. Furthermore, for trade liberalization to succeed in providing the "discipline" of world prices, unconstrained imports and exports should be permitted. Accordingly, a significant degree of current-account convertibility should be adopted. To enable the introduction of such convertibility, the financial system 
needs to be functional. These considerations imply that the benefits from, and support for, trade liberalization can be enhanced by well-functioning domestic capital markets.

\section{Sequencing and safety nets}

Attaining the conditions conducive to a transformation of a "bad" equilibrium into a "good" equilibrium, is not an easy task. Many obstacles need to be removed. Interest groups are well entrenched, the legal system protecting private ownership and property rights is not fully developed, managerial and technical know-how is linited, the banking system is underdeveloped, and the fiscal and monetary systems are ineffective. In addition, experfence with the operation and "rules of game" of a market economy is lacking, and policy credibility can only be earned over time.

The foregoing difficulties have stimulated interest in the analysis of the optimal pace and sequence of economic reform measures (see, for example, Dornbusch (1990), FIscher and Gelb (1990), Kornal (1990), Marer (1990) and Mckinnon (1991)). Experience suggests, however, that there is a danger that a lengthy search for a perfect sequence of economic measures under conditions of fast-changing circumstances, may result in the adoption of outdated and irrelevant policles. Rather, it might be preferable to adopt a timely, albeit somewhat imperfect, comprehensive reform program than to search the "perfect" fine-tuned sequence of policy actions.

In practice, however, there are circumstances in which the adoption of a rapid and comprehensive reform are impeded by a significant obstacle: the political support necessary for the adoption of such a program is lacking, thereby reducing its credibility. Without credibility, it may not be 
desirable to undertake the "first-best" program, since the lack of credibility amounts to a distortion, and calls for an application of the theory of the "second best" (Calvo (1989)). Thus, choices need to be made as to the appropriate pace and sequence of reform measures. In this regard, there is no general blueprint. Indeed, the basic insight of the theory of the second best implies that the optimal pace and sequence of reform measures depends on circumstances, and those, in turn, differ across countries. These circumstances reflect diversities of historical backgrounds, economic, legal, and political institutions, entrepreneurial traditions, as well as attitudes towards the role of markets and incentives. Since credibility plays a critical role in determining the success of the economic transformation program, it is important that the measures implemented early in the sequence are backed by a broad-based political support. To secure such support, the positive results of these measures should be quickly visible, and the appropriate "safety nets" necessary to protect the weak segments of society should be in place. These considerations explain why economic transformation programs adopted by highInflation countries (like Poland in 1990), should give high priority to achieving macroeconomic stabilization.

In choosing safety nets, additional obstacles need to be overcome. In addition to minimizing the welfare cost of taxation and income transfers, the safety nets should not interfere with monetary and exchange rate policies. In this regard, policies affecting the levels of interest rates and the exchange rate should not be held hostage to the objectives of protecting specific sectors in the economy. Likewise, the benefits from the 
safety net of wage indexation should be weighed against the cost of stimulating inflation. In general, expenditures assoclated with all safety nets should not impede macroeconomic stability: these expenditures should be accounted for, and be an explicit part of the budget process.

In previous sections, we have argued that the success of economic transformation in PCPEs hinges on the presence of well-functioning capital markets. We have also argued that an early development of such markets is desirable, as it removes numerous obstacles. Ideally, therefore, like macroeconomlc stability, financial-markets reform should also be given high priority in the sequence of transformation measures. However, since credibility plays a unique role in financlal markets, the lack of credibility is an obstacle hindering such reform. Therefore, a complete reform of the financial market may need to await the buildup of credibility. In this regard, however, a distinction should be made between liberalization of transactions in the domestic capital market and in the external one. The vulnerability of the latter to incomplete credibility is particularly acute in economies undergoing transformation. This explains why the opening of the capital account of the balance of payment (the adoption of capitalaccount convertibility) should be undertaken late in the sequence of policy measures, after trade liberalization (see, Edwards (1985) and Frenkel (1983))

The focus of this paper has been on obstacles prominent during the early stages of economic transformation. Excluded are obstacles prominent In the late stages of transformation--those that impede the resumption of sustainable growth (for an analysis of this issue, see Calvo and Frenkel $(1991 b))$. 


\section{References}

Borensztein, Eduardo, and Manmohan S. Kumar, "Privatization in Eastern Europe, " unpublished manuscript, International Monetary Fund Washington, October 1990.

Brainard, Lawrence J., "Reform In Eastern Europe: Creating a Capital Market," Economic Review, Federal Reserve Bank of Kansas City, January/February 1991, 49-58.

Calvo, Guillermo A., "Incredible Reforms," in G. Calvo, R. Findlay, P. Kouri and B.de Macedo (eds.) Debt. Stabilization and Development: Cambridge, Mass.: Bas1l Blackwe11, 1989, 217-34.

Calvo, Guillermo A., and Jacob A. Frenkel, "From Centrally-Planned to Market Economies: The Road CPE to PCPE, "Staff Papers, IMF, Vo1. 38, No. 2, June 1991, 268-299.

Calvo, Guillermo A., and Jacob A. Frenkel, "Transformation of CentrallyPlanned Economles: Credit Markets and Sustainable Growth," in Central and Eastern Europe: Roads to Growth. International Monetary Fund, 1991b, forthcoming.

Dornbusch, Rudiger, "Economic Reform in Eastern Europe and the Soviet Union: Priorities and Strategy," unpublished manuscript presented at OECDWorld Bank Conference on "The Transition to a Market Economy In Central and Eastern Europe," Paris, November 1990.

Edwards, Sebastian, "The Order of Liberalization of the External Sector in Developing Countries," Essays in International Finance, International Finance Section, Princeton University, 161, 1985. 
Fischer, Stanley, and Alan Gelb, "Issues in Socialist Economy Reform," presented at O.E.C.D. -World Bank Conference on The Transition to a Market Economy in Central and Eastern Europe, Paris, November 1990.

Frenke1, Jacob A., "Panel Discussion on Southern Cone," Staff Papers, International Monetary Fund, March 1983, 30, 164-73.

Frydman, Roman, and Andrzej Rapaczynski, Markets and Institutions In Large Scale Privatizations," unpublished manuscript presented at the World Bank Conference on "Adjustment and Growth: Lessons for Eastern Europe," Poland, October 1990.

Kornal, Janos, The Road to a Free Economy. Shifting from a Socialist System: The Example of Hungary; New York: W.W. Norton and Company, 1990.

Lipton, David, and Jeffrey Sachs, "Creating a Market Economy in Eastern Europe: The Case of Poland," Brookings Papers on Economle Activity, January 1990a.

Marer, Paul, "Pitfalls in Transferring Market-Economy Experiences to the European Economies in Transition, " unpublished manuscript presented at OECD-World Bank Conference on "The Transition to a Market Economy in Central and Eastern Europe," Paris, November 1990.

McKinnon, Ronald I., The Order of Economic Liberalization: Financial Control in the Transition to a Market Economy, 1991, forthcoming. 